\title{
Features of a Chemical Composition of Dry Leaves of Stevia vebaudiana
}

\author{
IRINA BORISOVNA KRASINA and \\ NATALIA ALEKSANDROVNA TARASENKO \\ FGBOU VPO "Kuban State Technological University" \\ Moskovskaya Street 2, Krasnodar,350072,Russia. \\ *Corresponding author E-mail: mtrushin@mail.ru
}

http://dx.doi.org/10.13005/ojc/320243

(Received: March 20, 2016; Accepted: April 15, 2016)

\begin{abstract}
This work is dedicated to the study of a chemical composition of dry leaves of Stevia. Dry leaves of Stevia contain diterpene glycosides that contribute to their sweet taste, which makes possible the use of Stevia as a sugar substitute in a production of flour confectionery products. The evaluation of amino acid composition of dried leaves of Stevia showed that their composition includes 7 essential amino acids, among them the limiting amino acid is valine.During experimental researches it was established that they are containing in a sufficient quantity water-soluble and fat-soluble vitamins in their composition. We have studied the effect of processing conditions on the degree of milling of dry leaves of Stevia. It was revealed that the pressure of $5 \mathrm{MPa}$ in the contact zone of the working elements do not guarantee a product with a desired degree of milling. Milling of dried leaves of Stevia at a pressure equal to $10 \mathrm{MPa}$, allows achieving a high degree of size reduction with a simultaneous formation of the main physical and chemical characteristics of amilledproduct. It was established that granulometric composition of dry leaves of Stevia, obtained by milling in a rotor-roller disintegrator, presents the highest content of particles with a size from 5 to $30 \mathrm{im}$, ensuring high consumer properties of the obtained biologically active additives (BAA).
\end{abstract}

Keywords:Stevia, chemical composition, biological value.

\section{INTRODUCTION}

The analysis of available information showed that at the present time many studies are being conducted on the use of a single species of plant raw materials, allowing creating multifunctional biologically active additives, containing in its composition of physiologically functional ingredients.

Of a particular interest from plant material is Stevia. Currently, Stevia is cultivated and used around the world for its incredible sweetening properties. It was studied for potential beneficial 
effects on diabetics. It has been shown that it slows the growth of a plaque in the mouth, and also has an anticaries action. Many studies have shown that Stevia is a safe product for human use, and it is now widely used as a sugar substitute botanical name of stevia is Stevia Vebaudiana and common names are honey yerba, candy leaf ${ }^{1}$.

The largest consumer of Stevia is Japan. In the late sixties when the Japanese government has forbiddedsome artificial sweeteners due to the concern about their influence for a health, the use of Stevia as a natural alternative increased significantly. The use of Stevia has also increased due to the concern of Japanese consumers about a health condition while using sugar, which is associated with caries, obesity and diabetes. It should be noted that a significant part of Japanese Stevia is consumed directly as a sugar substitute ${ }^{1}$.

The penetration of Stevia on the market in the industrialized countries began with a Japan. In 1985 in Japan there were already of 38 companies producing Stevia based dairy products (mainly yogurt), 26 companieswere producing diet sweets, 8 companies - a chewing gum, 7 companies - a

Table 1: Chemical Composition of Dry Leaves of Stevia

Indicator of a name Value of indicator

\begin{tabular}{lc}
\hline Mass fraction of (\%): & $10-11$ \\
water & $9,40-10,70$ \\
proteins & $0,50-1,90$ \\
lipids & $26,58-28,19$ \\
carbohydrates, including: & $0,82-1,14$ \\
monosaccharides & $0,61-1,40$ \\
disaccharides & $1,57-1,73$ \\
starch & $23,58-23,92$ \\
dietary fiber, including: & $15,30-16,40$ \\
fiber & $1,62-1,75$ \\
pectin & $37,70-38,10$ \\
extractives, including & $16,8-17,2$ \\
diterpene glycosides & $2,10-3,00$ \\
tannins & $2,55-3,07$ \\
oxycinnamic acids & $8,37-8,75$ \\
ash & $0,85-1,53$ \\
chlorophyll & \\
\hline
\end{tabular}

powder drink, 5 companies - an ice cream, 4 companies - fruit preserves and 3 companies were producing a Stevia based confectionery (chocolate, candy, cakes, cookies).

The consumption of products based on Stevia is more than 10 thousand tons per year. Over the 20 years in Japan were developed and implemented in the production and a healthcare system of more than 300 patents, copyrights and technology for the use of Stevia ${ }^{2}$.

Open joint-stock companythe scientificproduction holding association "Stevia-Agromedfarm" has developed a method of obtaining extract from the plant Stevia rebaudiana Bertoni, providing for obtaining an aqueous extract (in the ratio of water and raw materials from $1,5: 1,0$ to $9,0: 1,0$ ), purification of the extract, its evaporation and drying to obtain a residual humidity of $1.5-2.0 \%{ }^{3}$.

In the cooperation ofa Department of a Food Biotechnology and Conservation and a Moscow State Correspondence Institute of Food Industrywasdeveloped a resource-saving technology of processing of Stevia leaves, both fresh and dried, providing not only powdered preparations of Stevia, but also a number of dry extracts and pastes.

For providing of a soft and gentle technological modes during the processing of Stevia leaves we used a processesofhydroacoustic extraction of stevioside with the activated water, membrane (ultrafiltration, diafiltration, reverse osmosis) and ion exchange methods for purification and concentration, as well as a low-temperature drying in a boiling layer.

Table 2: Amino Acid Composition of Stevia Leaves

\begin{tabular}{lcc}
$\begin{array}{l}\text { The name of } \\
\text { amino acids }\end{array}$ & $\begin{array}{c}\text { Dry leaves of Stevia } \\
\text { A }\end{array}$ \\
\hline Isoleucine & 3,0 & C \\
Leucine & 3,7 & 75,0 \\
Lysine & 3,2 & 52,9 \\
Phenylalanine+tyrosine & 4,3 & 58,2 \\
Threonine & 1,93 & 71,7 \\
Valine & 1,90 & 48,3 \\
\hline
\end{tabular}


A feature of these processes is that they all occur at theenvironmenttemperatures, without phase transformations and preservesthenatural chemical structure of stevioside in a high degree ${ }^{4}$.

Traditionally Stevia is used as a sweetener to sweeten teas and soft drinks for a prophylactic use, to improve the organoleptic properties of the product, to reduce the caloric content and to increase the stability during a storage ${ }^{5,6}$.

Diterpene glycosides of the leaves and stems of Stevia are proposed to use not only as a low calorie dieting sweetening matter, but also to enhance and modify the odor of flavoring compositions used in the manufacture ofsoft drinksand other products $^{7,8}$.

Stevia is not destroyed when heated, so it can be used in food products that have been subjected to a thermal treatment. Stevia is a "flavor enhancer" as well as a sweetener ${ }^{9-11}$. This helps to bring out the true flavors in confectionery and bakery products, juices, berries, sorbets, candies, yogurt, ice cream and chewing gum ${ }^{12}$, gummy candy ${ }^{13}$, brines, toothpaste in addition to sweetening ${ }^{14}$.

Stevia is recommended as a remedy for bleeding gums and as a gargling for sore throatsbecause of itsantibacterial effect, and it is also inhibits the development of caries plaque and cavities ${ }^{14}$. Stevia can be used externally as a component of cosmetic masks. Although Stevia is promoted in Brazil as the antidiabetic remedy, but a research about the impact of Stevia on the metabolism of sugar in the blood is far from complete.

In the U.S. the widespread use of processed products of Stevia began in 1995, and in 1997 the Pentagon has completely replaced the entire diet of the US army. In the cooperation with the Institute of chemistry and Medical state University of Moldova the necessary tests and the official registration of Stevia in the Pharmacopoeia of the Republic of Moldova have been done.In the cooperation with the Moscow Institute of food concentrates industry and a special food technology were developed the technological instructions for the production of tea with Stevia, and together with the Scientific-Research And Design
Technological Institute Of Food Industryof Moldova were developed the specifications for"Dried Stevia", for"Stevia extract", for "Fruit juices with a pulp (nectar) with Stevia extract, "Compotewith Stevia extract" ${ }^{15}$.

In the cooperation of Institute of physiology, genetics and bioengineering of plants ofthe Ministry of science ofAcademy of Sciences of Kazakhstan and the Almaty Institute of technology was conducted an experimental work aimed for studying the possibility of using the powder of leaves of Stevia in the production of wheat breads (with an optimal dosage of Stevia of 0,08-0,1\%) ${ }^{16}$.

Thus, the analysis of scientific literature and patent information leads to the conclusion that Stevia is a valuable raw material for obtaining various products: extracts, etc. However, currently we have almost no highly effective technologies of processing of Stevia that allow us to obtain a complex of BAA with a maximum preservation of physiologically functional ingredients on its basis.

It is well known that one of the ways of controlling the properties of vegetable raw materials with maximum preservation of the entire complex of physiologically functional ingredients is the method of mechanochemical activation ${ }^{17}$.

Taking into the consideration that the created products should have not only a high nutritional and physiological value and high consumer properties, but also the optimal cost, a plant material was taken as the objects of a research, which is growing on the territory of Russia - Stevia (Stevia rebaudiana bertoni) of varieties Dulcinea, grown up on the Crimean experimental breeding station of VIR (Krasnodar region), and the secondary resources fat free spicy-aromatic plants.

Stevia (Stevia rebaudiana, honey herb) is a perennial shrub of the Aster family, growing in warm regions (Brazil, China, etc.). In nature its height is about $60-80 \mathrm{~cm}{ }^{18}$. There are almost 300 species of Stevia growing in America, but only Stevia rebaudiana has a sweet taste.

Russia has the possibility of growing honey grass. For the first time since 1996 in the State register of breeding achievements approved for 
use in the Russian Federation was included a new valuable technical culture of Stevia herb (Stevia rebaudiana Bertoni). The three varieties of domestic breeding are recommended for use: Detskoselsky, Ramon sweet tooth, Dulcinea.

Even if Stevia is a tropical culture, the possibility of its successful cultivation in some regions of the Russian Federation and even the possibility of cultivation of Stevia as a perennial crop in the southern part of Krasnodar Area are proved, of course if the breeding and release of varieties are suited to the regional circumstances. And the harvest here is nearly up to $2-2,5$ tons of dry leaf per $1 \mathrm{ha}^{19}$.

Stevia is cultivated in the Voronezh region, in the forest zone, sub-zone of southern taiga, in the Leningrad region - in Pushkin city, in the zone of steppes and semi steppes, in Volgograd, in the foothills of the North Caucasus, in the Krasnodar region. There is a possibility of Stevia cultivation in the city of Krymsk.

Stevia is the youngest agricultural crops in modern Russia. A technology of cultivation and processing of Stevia involves the cultivation of seedlings and plants, cleaning and drying the leaves, processing of stems ${ }^{20}$.

Table 3: Composition and Vitamin Content in Dry Leaves of Stevia

\begin{tabular}{lc}
\hline Name of vitamins & The content \\
\hline Water-soluble vitamins, \\
mg \%: \\
$\mathrm{P}$ & $71,24-71,87$ \\
$\mathrm{~B}_{2}$ & $35,42-36,17$ \\
$\mathrm{~B}_{1}$ & $9,45-11,30$ \\
$\mathrm{~B}_{6}$ & $9,07-10,12$ \\
$\mathrm{C}$ & $7,80-9,53$ \\
$\mathrm{PP}$ & $3,46-4,73$ \\
Fat-soluble mg\%: & \\
vitamins, & \\
$\mathrm{E}$ & $22,85-24,24$ \\
$\beta$-carotene & $4,74-5,46$ \\
\hline
\end{tabular}

The objects of research were dry leaves of Stevia (Stevia rebaudiana bertoni), collected during flowering and dried at a temperature of $55-60^{\circ} \mathrm{C}$, when the enzymes that destroy glycosides inactivates ${ }^{21}$.

\section{METHODS}

Mass fraction of protein was determined using the system of quantitative identification $\mathrm{N} 2$ /protein DKL8 of the manufacturer "VELP SCIENTIFICA", Italy. The biological value of the powder of seeds ofsainfoin was studied by experimental determination of amino acid composition with use system of capillary electrophoresis "KAPEL105 " of the manufacturer "Lumex", Russia 22.

Mass fraction of fiber was determined at the device for the analysis of fibre FIBRETHERM FT12 of the manufacturer "Gerhardt", Germany in accordance witha State standart of Russian Federation \#10846-91.

Mass fraction of fat was determined on an automaticdevice for solid-liquid extraction SOXTHERM SOX414a of the manufacturer "Gerhardt", Germany ${ }^{23}$. Determination of the mass

Table 4: Qualitative and Quantitative Composition of Mineral Elements in Dry Leaves of Stevia

\section{Name of mineral elements The content}

Mass of fraction of microelements, mg/100 g:

\begin{tabular}{lc} 
Calcium & $2853-3035$ \\
Potassium & $1585-1915$ \\
Magnesium & $1097-1360$ \\
Sodium & $496-520$ \\
Phosphorus & $494-603$ \\
Mass fraction of & \\
microelements, mg/kg: & \\
Iron & $48,00-61,00$ \\
Zinc & $33,80-34,39$ \\
Manganese & $14,00-14,56$ \\
Chrome & $11,25-11,87$ \\
Copper & $7,09-7,84$ \\
Selenium & $0,31-0,33$ \\
\hline
\end{tabular}


fraction of carbohydrates, including mono - and disaccharides, was carried out by chromatography on a liquid chromatograph of high pressure in a mixture of acetonitrile - water (77:23).

Quantitative determination of the diterpene glycosides was calculated according to the intensity of the color spot and was performed on a densitometer of a German production.

Mass fraction of macro - and microelements (potassium, sodium, calcium, magnesium, iron, manganese, chromium, zinc and copper) in dry leaves of Stevia and in fat-free spicy-aromatic raw materials was determined by atomic absorption spectrophotometry (AAS) on the analyzer AAS-1 made by "Zeiss", Germany.
The evaluation of the results of experiments was made with the use of modern methods of calculation of static reliability using the programs Statistica 6.0, Microsoft Office Excel 2007 and Mathcad.

All studies were made on the equipment ofthe center for a collective use"A researching center of food and chemical technologies" of a Federal state budgetary educational institution of additional professional education"Kuban state technological University".

\section{RESULTS}

Table 1 shows the chemical composition of dry leaves of Stevia (Stevia rebaudiana Bertoni).

Table 5: Indicators of the safety of dry leaves of Stevia

\begin{tabular}{|c|c|c|}
\hline $\begin{array}{l}\text { Indicator } \\
\text { name }\end{array}$ & $\begin{array}{l}\text { Permissible } \\
\text { levels }\end{array}$ & $\begin{array}{l}\text { Value of } \\
\text { indicator }\end{array}$ \\
\hline \multicolumn{3}{|l|}{ Microbiological indicators: } \\
\hline $\begin{array}{l}\text { The number of mesophilic } \\
\text { aerobic and facultative anaerobic } \\
\text { microorganisms } \\
\text { (The colony forming unit } / \mathrm{g} \text { ), not more }\end{array}$ & $5 \times 10^{4}$ & $(2,0-2,5) \times 10^{2}$ \\
\hline $\begin{array}{l}\text { Bacteria of group of } \\
\text { intestinal sticks (in } 0,01 \mathrm{~g} \text { ) }\end{array}$ & not valid & not found \\
\hline $\begin{array}{l}\text { Pathogenic microorganisms, } \\
\text { including Salmonella }\end{array}$ & $\begin{array}{l}\text { in } 25,0 \mathrm{~g} \\
\text { not valid }\end{array}$ & $\begin{array}{l}\text { in } 25,0 \mathrm{~g} \\
\text { not found }\end{array}$ \\
\hline $\begin{array}{l}\text { Mold, (The colony forming unit } / \mathrm{g} \text { ), } \\
\text { not more } \\
\text { Toxic elements, } \mathrm{mg} / \mathrm{kg} \text { : }\end{array}$ & 100 & $30-35$ \\
\hline lead & 0,5 & $0,085-0,100$ \\
\hline arsenic & 0,2 & not found \\
\hline mercury & 0,02 & not found \\
\hline cadmium & 0,03 & not found \\
\hline $\begin{array}{l}\text { Pesticides, } \mathrm{mg} / \mathrm{kg} \text { : } \\
\text { hexachlorocyclohexane ( } \alpha, \beta, \lambda \text { - isomers) }\end{array}$ & 0,5 & not found \\
\hline $\begin{array}{l}\mathrm{DDT} \text { (dichlorodiphenyl } \\
\text { trichloromethyl-methane) and its metabolites } \\
\text { Radionuclides, } \mathrm{Bq} / \mathrm{kg} \text { : }\end{array}$ & es & not found \\
\hline cesium -137 & 130 & $4,9-5,6$ \\
\hline strontium -90 & 50 & $2,8-3,5$ \\
\hline
\end{tabular}


The data show that the dry leaves of Stevia contain diterpene glycosides that contribute to their sweet taste, which makes possible the use of Stevia as a sugar substitute in the production of flour confectionery products. Analyzing of table 1 it should be noted that Stevia contains in its composition physiologically valuable substances.

Taking into the consideration that the biological value is also determined by the amino acid composition of proteins, it was of a great interest to determine all the investigated materials.
Table 2 shows data on the composition of the essential amino acids of Stevia.

The evaluation of the amino acid composition of dried leaves of Stevia, as can be seen from table 2 , showed that their composition includes 7 essential amino acids, the limiting amino acid is valine $(38,0)$.

Table 3 summarizes data on the composition and vitamin content in dry leaves of Stevia.

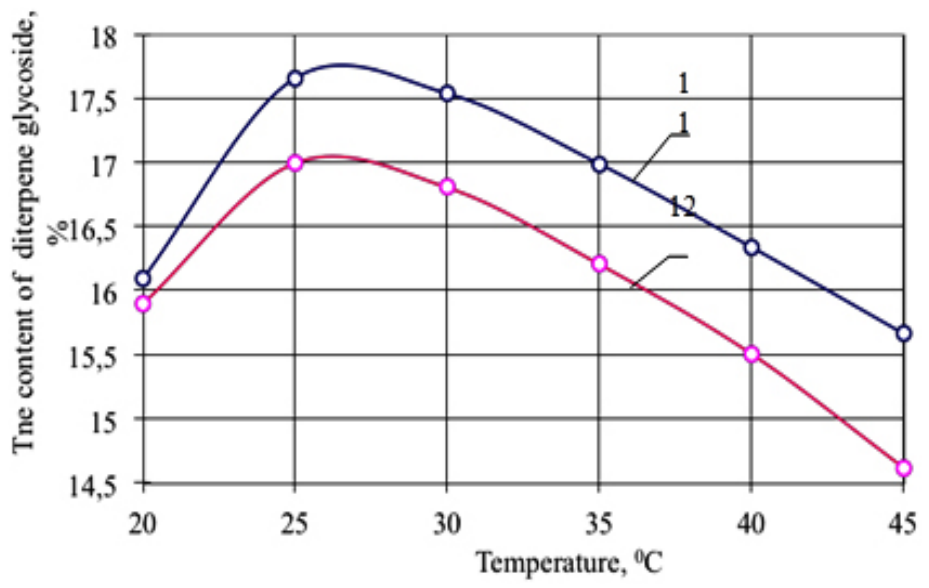

Fig. 1: Influence of a mechanochemical activation in the processing of dried leaves of Stevia in the hoses of high pressure for the content of diterpene glycosides: $1-5 \mathrm{MPa} ; 2-10 \mathrm{MPa}$

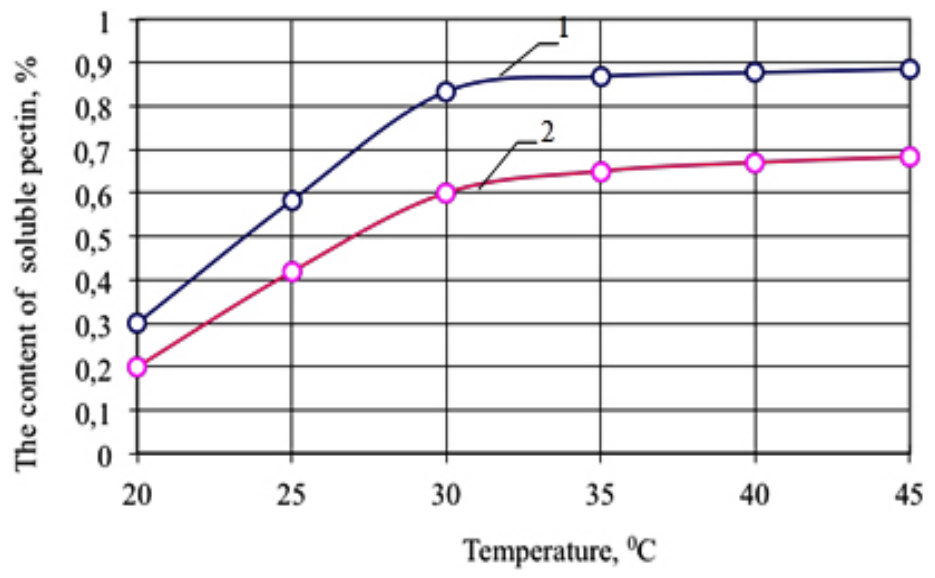

Fig. 2 : Influence of a mechanochemical activation in the processing of dried leaves of Stevia in the hoses of high pressureon the content of soluble pectin in the resulting

product: 1 - $5 \mathrm{MPa}$; 2 - $10 \mathrm{MPa}$ 
The data show that the Stevia leaves are containing in its composition water - soluble and fatsoluble vitamins in a sufficient quantity.

Taking into the consideration the importance of macro - and micronutrients for the diet of the population who are at risk of diabetes mellitus and who are already the diabetic patients were analyzed a quantitative and a qualitative composition of Stevia leaves (table 4).

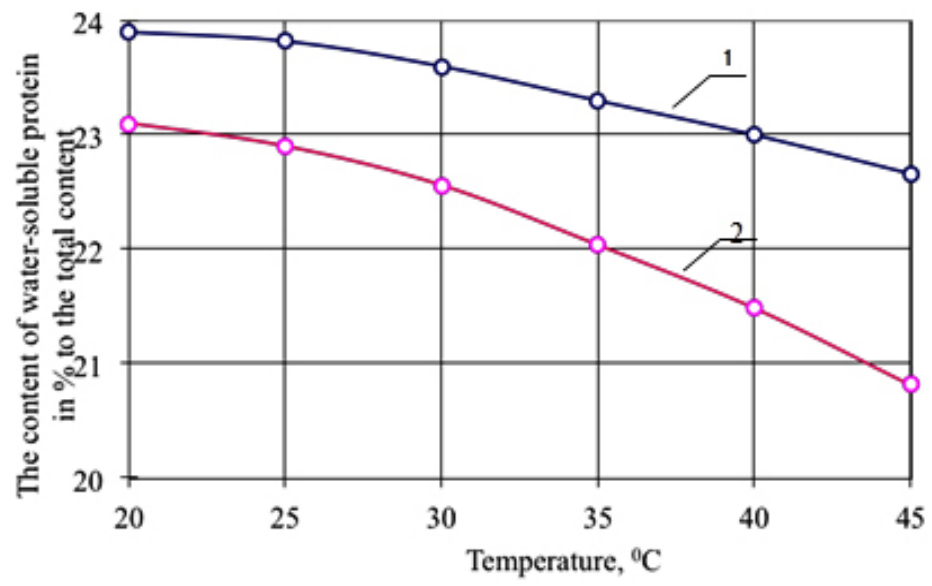

Fig. 3: Influence of a mechanochemical activation in the processing of dried leaves of Stevia in thehoses of high pressureon the content of water-soluble fractions of proteins in the resulting product: 1 - $5 \mathrm{MPa} ; 2$ - $10 \mathrm{MPa}$

Table 7: The Effect of Mechanical and Chemical Activation on the Organoleptic, Physical and Chemical Characteristics of Leaf Powder of Stevia

Indicator name

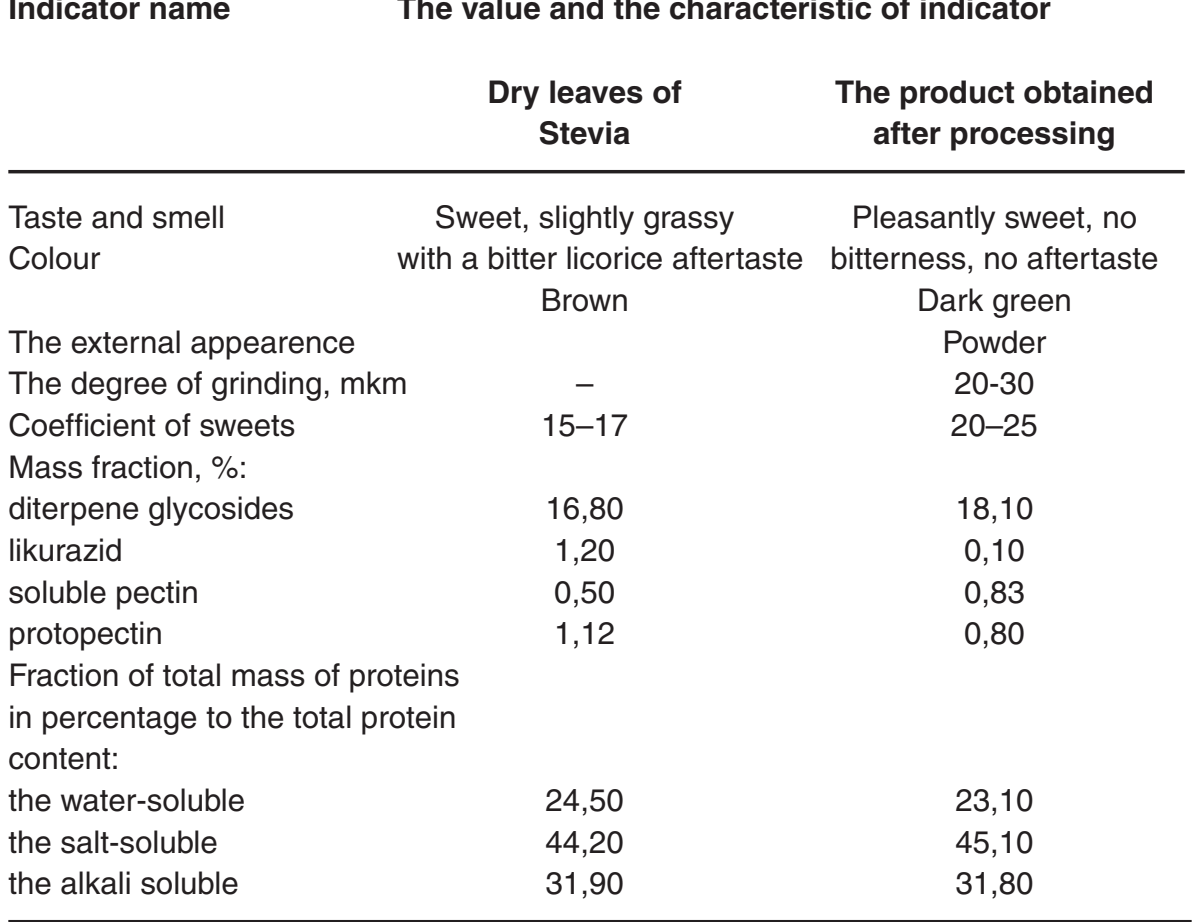


From these data we can conclude about a rich mineral composition of dry leaves of Stevia. Was also investigated the safety of Stevia leaves, the results are presented in table 5 .

We conducted some special experiments aimed to research the influence of temperature and mechanical activation on the organoleptic and physical and chemical characteristics of dry leaves of Stevia in the course of their treatment.

The mechanochemical activation of dry leaves of Stevia was carried out in a rotorroller disintegrator of a vertical type. A design was developed by the staff of the Department of technology of fats, merchandising, processes and apparatus of a food production of Kuban state technological University.

A design of a rotor-roller disintegrator allows the simultaneous processing of vegetable raw materials and its milling, and also allows the creatingof high pressure gradients from 60 to 100 $\mathrm{MPa}$ and a pulsating load with a frequency of up to $400 \mathrm{~Hz}$.

Temperature of a processing of dried leaves of Stevia in a rotor-roller disintegrator varied in the range from 20 to $500 \mathrm{C}$ and the pressure during processing was from 5 to $20 \mathrm{mpa}$.

Table 6: Grain Size Composition of Biologically Active Additives from Stevia

\begin{tabular}{lc}
\hline $\begin{array}{l}\text { Size fraction, } \\
\text { microns }\end{array}$ & $\begin{array}{c}\text { The contents of } \\
\text { fractions }\end{array}$ \\
\hline $\begin{array}{l}\text { More then } 100 \\
100-65\end{array}$ & 0,1 \\
$64-50$ & 0,42 \\
$49-40$ & 0,48 \\
$39-30$ & 3,60 \\
& \\
$29-20$ & 12,50 \\
$19-10$ & 37,40 \\
$9-5$ & 39,22 \\
Less then 5 & 6,28 \\
\hline
\end{tabular}

The efficiency of technological modes was evaluated according to the degree of millingof dry leaves of Stevia in a rotor-roller disintegrator.

The effect of processing conditions on the degree of milling of dry leaves of Stevia was studied. It was revealed that the pressure of $5 \mathrm{MPa}$ in the contact zone of working elements ensures a product with a desired degree of milling. Milling dried leaves of Stevia at a pressure of $10 \mathrm{MPa}$, allows achieving a high degree of size reduction with simultaneous formation of the main physical and chemical characteristics of the milled product.

Figure 1 shows the dependence of the effect of mechanochemical activation on the content of diterpene glycosides, and triterpene saponins, and figures 2 and 3 - the influence of a mechanochemical activation on the content of soluble pectin and watersoluble fractions of proteins.

The data show that increasing the temperature up to $450 \mathrm{C}$ leads to an increased yield of diterpene glycosides, a further increase in temperature leads to the decrease of their content, which, apparently, is connected with a partial destruction of glycosides. The maximum reduction of triterpene saponins in the achieving of a high organoleptic, physical and chemical parameters, as well as the preservation of biologically active substances are achieved in the processing of dried leaves of Stevia in a rotor-roller disintegrator at a temperature of $30^{\circ} \mathrm{C}$ and a pressure of 5 .

It should be noted that during the processing there has been a slight decrease in the content of soluble pectin. The mechanochemical treatment of dry leaves of Stevia in a rotor-roller disintegrator leads to the destruction of polymeric carbohydrates, and protopectin, which forms the basis of pectocellulose membranes of water-soluble proteins, which, apparently, are connected with a short-term mechanical impact on the product, resulting in the destruction of the polymeric protein molecules with the formation of free amino acids. While growing cells, are converted into soluble pectin.

Table 6 shows the data on granulometric composition of amilled product. 
The data show that the granulometric composition of dry leaves of Stevia, obtained by a milling in a rotor-roller disintegrator, presents the highest content of particles with a size from 5 to $30 \mu \mathrm{m}$, to ensure high consumer properties of the obtained biologically active additives. Table 7 shows the organoleptic, physical and chemical characteristics of biologically active additive obtained by the processing of dried leaves of Stevia in a rotorroller disintegrator at the specified modes.

\section{DISCUSSION}

Our studies have shown that a safety indicator of dry leaves of Stevia correlate with the safety requirements to the additives and products of vegetable origin.

Taking this into the consideration, it can be concluded that dry leaves of Stevia are a valuable raw material for the creating of BAA and they are the main components of functional foods, however, it is necessary to develop special technological modes of processing.

It is known that the sweet taste of the leaves of Stevia is due to diterpene glycosides, and a bitter licorice flavor is due to some of the isomers of diterpene glycosides, and a presence of triterpene saponin - likurazid.
The obtained experimental data allowed recommendingthe investigated BAA for the production of a functional food ${ }^{24}$.

\section{CONCLUSION}

Theoretically and experimentally it was proved the feasibility and efficacy of Stevia (Stevia rebaudiana bertoni) and of some aromatic fatfree plants as a raw material for producing of a physiologically functional BAA.

It was shown that the processing of Stevia and of some aromatic fat-free plants using the method of mechanochemical activation (MCA) allows to obtain BAA with high consumer properties and nutritional value and physiological activity.

\section{ACKNOWLEDGMENTS}

The work was performed for the grant of President of Russian Federation for the State support of young Russian scientists - candidates of Sciences (MK-4970.2016.11) on "The biochemical study of microstructure of a food fibre to create preventive confectionery products with the use of modern methods of nutrimetabolics".

\section{REFERENCES}

1. David Richard. Stevia rebaudiana: Nature $S$ Sweet Secret.USA,2000,190.

2. Pavlova G. N. Stevia as a sugar substitute // Bulletin of agricultural science.1995, 1,5-8.

3. Patent \# 2198548 RU, MPK7 À23L1/236. Method of obtaining extracts from the plant Stevia rebaudiana Bertoni / V. N. Lisitsyn, H. H. Melikhodzaevich (RF).2.

4. Golubev V. N., M. G. Hedrich M. G., I. A. Rusakova. The resource-saving technology of a natural food sweetener - steviozide, Food industry. 1997,5,10-11.

5. Pat. 2000121043RU, MPK7 À23L2/00. The method of preparing a tea beverage G. I. Beletskaya (Russia).p C.

6. Pat. 93041964 RU, MPK6 À23F3/34. Soft drink
G. N. Pavlova, L. D. Erashova, L. A. Alekhina, Nesvetailo V. I. (Russian Federation).-p C. Tsanava, V. P.,Sardjveladze G.P., Kharebava L.G. The influence of some technological methods on the content of a volatile compounds of asweet dualleaf grass,. The subtropical crops.1991,3 (233),64-70.

8. Tsanava, V. P., P. G. Sarjveladze, Kharebava L. G. Investigation of volatile compounds of sweet dualleaf,. Subtropical crops. 1989,3(221),7377.

9. Ataev A. A. Bakery products for a medical nutrition Baking in Russia. 2000,2,31-32.

10. Jakubekova L. O. Dietary bakery and confectionery products Bakery in Russia. $1999,1,22$. 
11. Shatnyuk L. N., NagoytsevaU.A. New types of confectionery dietary purposes. -M.: AgroNIITElpisheprom, 1991,5,32.

12. Pat. 2000130708 US, MPK7 W099/62354. Method of a speed regulating of release of $\mathrm{N}$-substituted derivatives of aspartame in chewing gum and a gum produced in accordance with this method,. Yatka Robert J., Townsend, Donald J., Greenberg Michael J. (US). 6.

13. Pakhomov A. N. Theoretical and experimental substantiation of a creation of functional food products and biologically active additives based on vegetable raw materials. The doctoral dissertation of tech. sciences: 05.18.15 Krasnodar, 2005,251.

14. Pat. 98121702 DE, MPK7 W097/41835. A method for improving the taste of solid preparations, the composition and the solid preparation with an improved taste,..Eugen Schwarz, Mishel Gernot (DE).2.

15. Miku V. E, Kisnican L. P., Bagdasarov, S. M. Stevia - a promising crop for the production of low-calorie and diabetic foods,. Food industry.1999, 10,32.

16. V. N. Golubev The state of a food production in Russia ,. Thesis of the III International Symposium "Human ecology: problems and status of a preventive nutrition", Moscow, 1994, 19-22.

17. Martoushuk V. I. Scientific and practical bases for a production of modified fats and fatty semi-finished products by the method of mechanochemical activation: The doctoral dissertation of tech. sciences: 05.18.06. Krasnodar, 2000,215.
18. GoyalS. K, Samsherand R. K. Goyal, Stevia (Stevia rebaudiana) a biosweetener: a review. International Journal of Food Sciences and Nutrition,. 2010,61, 1, DOI:10.3109/09637480903193049

19. TadhaniM.B., Patel V.H. and Rema Subhash,. In vitro antioxidant activities of Stevia rebaudiana leaves and callus. Journal of Food Composition and Analysis,. 2007,20,3-4, May 2007,323329. doi:10.1016/j.jfca.2006.08.004.

20. Tarasenko N.A., Krasina I.B. Developing procedures and recipes of dietary wafers with stevioside. European Journal of Physical and Health Education, 6, art. no. BM-009-14, 2014 ã. 2-s2.0-84907694645

21. Tateo F., M. Fugazza and S. Faustle,. Sullativa mutagena e modificatrice della fertilita di estratti della Stevia rebaudiana Bertoni. Riv. Ital. Sci. Alim,. 1990, 19, 1-2: 19-21.

22. MP 04-38-2009 System of capillary electrophoresis Kapel囚. Determination of the protein genic amino acids in compound feeds and raw materials.

23. Tarasenko N. A, Butina E. A, Gerasimenko E. O., Peculiarities of chemical composition of sainfoin seeds powder. Orient. J. Chem,.2015,31(3).1673-1682 Available from: http://www.orientjchem.org/?p=10557. DOI : http://dx.doi.org/10.13005/ojc/310346

24. Krasina I.B., Tarasenko N.A. Research way of obtain extracts from walnut leaves, their properties investigation on purpose to use them as ingredients during jelly fruit candy production. American-Eurasian Journal of Sustainable Agriculture, 2014, 8 (9),23-26. 2-s2.0-84907057278. 